\title{
International Marketing Strategies in the Jewellery Industry: Are They Standardised, Adapted or Both?
}

\author{
Diego Matricano $^{1} \&$ Giorgio Vitagliano ${ }^{1}$ \\ ${ }^{1}$ Department of Management, Università degli Studi della Campania “Luigi Vanvitelli”, Capua (CE), Italy \\ Correspondence: Diego Matricano, Department of Management, Università degli Studi della Campania "Luigi \\ Vanvitelli”, Corso Gran Priorato di Malta - 81043 Capua (CE), Italy.
}

Received: January 4, 2018 Accepted: January 26, 2018 Online Published: February 3, 2018

doi:10.5539/ijms.v10n1p1 URL: https://doi.org/10.5539/ijms.v10n1p1

\begin{abstract}
According to analysts and practitioners, five main trends characterise the future of the jewellery industry: internalisation and consolidation; market growth; a new channel landscape; hybrid consumption; and fast fashion. Among these, the process of internalisation, which is started and managed by local jewellery brands, seems of great interest. These brands, generally small and medium enterprises (SMEs), have to plan their international marketing strategies in order to face the biggest jewellery groups and compete worldwide.

In the present paper, through the methodology of a single case study of leBebè, an Italian brand, the standardisation and adaptation processes of international marketing strategies are rebuilt and investigated in reference to the jewellery industry. From the analysis, it emerges that the jewellery industry has specific dynamics that force companies to implement an international marketing strategy that falls halfway between standardisation and adaptation and is generally known as a contingency perspective. The achieved results strengthen the contingency perspective on the standardisation/adaptation debate and, above all, allow for speculating that international marketing strategies partly depend on the brand and mostly depend on the prominence of the brands and on factors characterising each industry.
\end{abstract}

Keywords: international marketing, standardisation, adaptation, contingency perspective, jewellery industry, luxury industry

\section{Introduction}

The report titled "A multifaceted future: The jewellery industry in 2020", edited by McKinsey \& Company (2014), contains a detailed and deep analysis of the jewellery industry. Data included in the report reveal that the industry has achieved positive results in recent years (in terms of net sales) and — above all—still more positive results are expected over the next two years. In this vein, analysts working at McKinsey \& Company (2014) have disclosed five main trends that characterise this industry: internalisation and consolidation; market growth; a new channel landscape; hybrid consumption; and fast fashion. Among these, the process of internalisation seems of great interest (McKinsey \& Company, 2014; Bain \& Company, 2015).

Local jewellery brands, generally small and medium enterprises (SMEs), aspiring to face the biggest jewellery groups and compete worldwide, need to plan and implement their international marketing strategies. In particular, they need to define whether their international marketing strategies are going to be standardised or adapted.

This topic of research — not only referred to in the jewellery industry but to all SMEs - is of great interest among management scholars (Theodosiou \& Katsikeas, 2001; Alashban et al., 2002; Zou \& Cavusgil, 2002; Ryans, Griffith, \& White, 2003; Theodosiou \& Leonidou, 2003; Kustin, 2004; Vrontis, Thrassou, \& Lamprianou, 2009; Schmid \& Kotulla, 2011; Chung, Wang, \& Huang, 2012; Akgün, Keskin, \& Ayar, 2014; Griffith et al., 2014).

Among them, Schmid \& Kotulla (2011) propose an extensive review and offer a theoretical framework useful for proceeding with further studies. Along this path, Griffith et al. (2014, p. 309) focus attention on the fact that local brands need to balance "multiple export relationships across a wide number of countries". Balancing multiple export relationships at the same time is not easy (Schmid \& Kotulla, 2011). For this reason, brands need to establish in advance whether to implement a standardised or adapted international marketing strategy.

According to Theodosiou \& Leonidou (2003), management scholars interested in the standardisation and adaptation processes of international marketing strategies can be divided into three groups. The first includes the 
scholars who support the standardisation process. This choice is due to the main benefits derived from a standardised process: economies of scale; a consistent image communicated across countries; and reduced complexity in managing operations (Theodosiou \& Leonidou, 2003, p. 142). The second group comprises the scholars who support the adaptation process. These scholars argue that international marketing strategies cannot be characterised by myopia since there is major profitability related to different consumers' needs across countries. Finally, the third group embraces scholars who support the contingency perspective. From this perspective, standardisation and adaptation run along the same continuum and, thus, need to be considered together. The choice between standardisation and adaptation is situation-specific (related to a specific market, industry and time) and, therefore, it cannot be easily generalised (pp. 142-143).

According to the above, the main aim of this paper is to investigate how jewellery brands define and implement their international marketing strategies. Put simply, the research question posed herein is: Do jewellery brands implement international marketing strategies addressed towards standardisation, adaptation or the contingency perspective?

In order to try to answer the above question, the paper proceeds as follows. In Section 2, titled "Literature review", the state of the art of the "4Ps"-product, pricing, placement and promotion - is revised. From an extensive literature review, it is rebuilt if companies standardise or adapt the 4Ps when they decide to enter international markets. In the last part of the section, a special focus on the jewellery industry is presented. In Section 3, "Methodology and data collection", why the single case study is used herein is explained. In Section 4, the leBebè case study is rebuilt and analysed. The Italian brand (launched in 2007) has already started its internationalisation process; thus, the choice of standardising, adapting or mixing its international marketing strategy has already been carried out.

According to the presented results, Section 5, labelled "Results and Discussion", offers some speculation about international marketing strategies. In particular, in reference to the jewellery industry, the results indicate that international marketing strategies partly depend on the brand and mostly depend on the prominence of the brand and on factors characterising the jewellery industry. These results strengthen the contingency perspective in the standardisation/adaptation debate.

\section{Literature Review}

Even if the earlier contributions date back to the 1960s (Vernon, 1966), it is since 1975-when Sorenson and Wiechmann started discussing the standardisation and adaptation processes of international marketing strategies - that several management scholars have contributed to this field of research (Kotler, 1986; Porter, 1986; De Luz, 1993; Dunning, 1993; Cavusgil \& Zou, 1994; Boddewyn \& Grosse, 1995; Johnson \& Arunthanes, 1995; Leonidou, 1996; Shoham, 1996, 2003; Theodosiou \& Katsikeas, 2001; Alashban et al., 2002; Zou \& Cavusgil, 2002; Ryans et al., 2003; Theodosiou \& Leonidou, 2003; Kustin, 2004; Griffith \& Myers, 2005; Vrontis et al., 2009; Powers \& Loyka, 2010; Schmid \& Kotulla, 2011; Chung et al., 2012; Boso et al., 2013; Akgün et al., 2014; Griffith et al., 2014).

Over these decades, the way scholars have approached this topic has completely changed.

Kotler's contribution (1986, p. 14) clarifies that a brand can evaluate three options: design its product for the local market only (local strategy); design one product and marketing program for the global marketplace (standardised strategy); or design national and regional adaptations in advance (adaptation strategy). According to Kotler, the local strategy is myopic and so it should be excluded a priori. The adaptation strategy seems to be the first-best choice. Through the adaptation processes of an international marketing strategy, brands can satisfy specific requests of specific markets (Akgün et al., 2014). If adaptation is not achievable, then the standardised strategy — the second-best choice — seems acceptable (Kotler, 1986).

In Theodosiou and Leonidou's contribution (2003), a brand can evaluate three different options: the standardisation process, the adaptation process, and the contingency perspective. At first glance, it appears that brands no longer consider local strategies. Nowadays, in fact, brands can consider standardisation, adaptation or the contingency perspective (Douglas \& Wind, 1987; Ohmae, 1989; Cavusgil, Zou, \& Naidu, 1993; Calantone et al., 2006; Birnik \& Bowman, 2007; Viswanathan \& Dickson, 2007; Schmid \& Kotulla, 2011). This last option is halfway between standardisation and adaptation and is based on the assumption that the international marketing strategy is situation-specific (depending on the market, industry and time) and cannot be easily generalised. Accordingly, brands can define some aspects by recalling a standardised strategy and others by referring to an adapted strategy. According to the contingency perspective, "the difference between standardisation and adaptation is in degree rather than in kind" (Theodosiou \& Katsikeas, 2001, p. 5). 
In this vein, particular attention needs to be paid to the 4Ps of the international marketing strategy (Omar, 2008; Goi, 2009). All four issues will be analysed and discussed.

As for product, Theodosiou \& Leonidou (2003) argue that, in most cases, it is standardised. Several operational aspects, i.e. economies of scale, better coordination of controlling quality standards, time to market and shorter lifecycles, seem to drive brands to act in this way. Shoham (1996) and Vrontis \& Papasolomou (2005) also share this view and underline the same benefits cited above. Instead, Loyka \& Powers (2003, p. 64) review "the history and background of global standardisation and provide a framework for future research on the topic". The scholars pay attention to market factors, industry factors and company factors that - in their view-affect the choice of whether to standardise or adapt the product. The main consequence is that the choice depends on the host country where the brands decide to export. However, some years later, the same scholars (Powers \& Loyka, 2010) argue that adapted products can strengthen the competitive position since they can satisfy specific requests made by specific targets. Today, the topic is still under discussion and opinions move from standardisation to adaptation, passing through the contingency perspective.

The same results can be achieved in reference to pricing. Theodosiou \& Katsikeas (2001), in fact, review the standardisation and adaptation schools of thought and, of course, consider the contingency perspective as a third option. Their review reveals that some scholars support the standardisation of international pricing (Theodosiou \& Katsikeas, 2001; Birnik \& Bowman, 2007; Powers \& Loyka, 2010). In this vein, Powers \& Loyka (2010, p. 67) underline that "when a product with the same brand name is sold in different countries, it can be difficult and sometimes impossible to sell them at different prices". Other scholars, however, assume that, in most cases, price is adapted (Levitt, 1983; Samli \& Jacobs, 1995; Shoham, 1996; Theodosiou \& Leonidou, 2003; Vrontis \& Papasolomou, 2005). This choice seems to be due to cost structures (related to the export strategy), competitive policies with local brands and government choices as well (taxes). In reference to the way the choice should be carried out, Tan \& Sousa (2011) propose a very useful framework, which includes: 1) firms and management characteristics; 2) product characteristics; 3) industry characteristics; and 4) foreign/domestic market characteristics. These four groups of factors affect the export pricing strategy and practices. In this case, it is clear that brands need to properly evaluate each host market before determining their pricing.

As argued by Solberg (2000), management scholars are used to underestimating the relevance of placements in international marketing strategies. Very scarce attention, in fact, has been paid to the role played by headquarters, on one hand, and subsidiaries (local sales offices, agents and distributors) on the other. In most cases, attention has been wrongly addressed only towards "the trade-off between culture and economies of scale" (Solberg, 2000, p. 81). A focal point, instead, should be control that — put simply — stands for the "balance between headquarters and subsidiaries" (p. 82). Seeking, achieving and keeping this balance are very tricky tasks since relationships can change across countries and over time. For this reason, several scholars support the idea of adapting placement in most cases (Shoham, 1996; Solberg, 2000; Theodosiou \& Leonidou, 2003; Vrontis \& Papasolomou, 2005; Powers \& Loyka, 2010). Some exceptions are acknowledged for large companies that rule the market and, as a consequence, can rule their relationships with subsidiaries as well.

Promotion is the last issue to analyse. Several management scholars have investigated this topic (Onkvisit \& Shaw, 1999; Sirisagul, 2000; Chandra, Griffith, \& Ryans, 2002). Even if there seems to be a general orientation toward the standardisation of promotions, and some scholars have conducted empirical researches to test the influence of market similarity, process standardisation, environmental similarity and mode of entry on advertising messages and packaging (Griffith, Chandra, \& Ryans, 2003), the results are still far from maturity. On one hand, promotion should be standardised since it mirrors the worldwide image of the brand; on the other hand, with differences in language, public relations and personal selling, the host country's culture plays a crucial role (Kustin, 2004; Powers \& Loyka, 2007, 2010), requiring promotion to be slightly adapted (Theodosiou \& Leonidou, 2003).

From the above review, it is derived that it is not possible to generalise whether brands implement a standardised or adapted international marketing strategy. As often emerged, the choice seems to be related to several factors, such as market, industry, company, economies of scale and culture. In reference to international marketing strategies on the whole, Theodosiou \& Leonidou (2003) identify seven antecedent factors that can affect the 4Ps: environmental factors; market characteristics; customer issues; competition; product and industry; organisational factors; and managerial factors. Of course, it is not possible to ignore the influence generated by previous experiences - if any - carried out by brands aiming to internationalise (Morgan, Kaleka, \& Katsikeas, 2004; Katsikeas, Samiee, \& Theodosiou, 2006).

For the above reasons, it seems appropriate at this stage to restrict the boundaries of the research by focusing 
only on the jewellery industry that —as one might expect—has specific dynamics. This is done in order to typify what was said above in reference to the 4Ps.

As anticipated by several scholars (Silverstein \& Fiske, 2003; Vickers \& Renand, 2003), luxury industries are changing. In order to summarise these changes, the scholars introduce the concept of new luxury that identifies "products and services that possess higher levels of quality, taste and aspiration than other goods in the category but are not so expensive as to be out of reach" (Silverstein \& Fiske, 2003, p. 1). In order to drive as many customers as possible to buy brands related to the concept of new luxury, it is important to investigate the factors affecting the shopping experience. According to a dedicated study (Sanguanpiyapan \& Jasper, 2010, pp. 158-159), jewellery shoppers are influenced by tangible and intangible attributes. The main five tangible attributes are merchandise, price range, products-needs fit, suitable hour and location. The main five intangible attributes are interaction with salesperson, self-gratification, knowledge of new trends, role-playing and diversion. From the above, it is clear that shoppers of jewellery brands are strongly interested in the shopping experience (Atwal \& Williams, 2009; Tynan, McKechnie, \& Chhuon, 2010). They want to live their own shopping experience when they decide to buy jewels and - above all — they are willing to pay a premium price to do so (Yeoman \& McMahon-Beattie, 2006; McKinsey \& Company, 2014; Bain \& Company, 2015). Surprisingly, in-store shopping is still predominant. However, Internet and TV shopping are growing fast and in a massive way (Okonkwo, 2009; Keller, 2010; Sanguanpiyapan \& Jasper, 2010; Baker et al., 2018).

The relevance of experience might sound good for jewellery brands. Within a global context, high levels of quality, taste and aspiration are similar even across countries. After choosing their favourite brand, which can be prominent or not in the jewellery and luxury industries (Han, Nunes, \& Drèze, 2010), worldwide shoppers would like to live their shopping experience and, thus, standardised international marketing strategies might be easily defined and implemented. Based on this assumption, the research question posed herein is: Do jewellery brands implement international marketing strategies addressed towards standardisation, adaptation or the contingency perspective? In order to try to answer the above question, a single case study about leBebè, an Italian jewellery brand launched by the company Lucebianca, is presented hereinafter.

\section{Methodology and Data Collection}

The way jewellery brands define and implement their international marketing strategies is not a quantitative phenomenon that can be measured. For this reason, a different approach is needed (Strauss \& Cobin, 1990; Yin, 1993; Lee, Collier, \& Cullen, 2007) and, actually, an inductive qualitative analysis seems suitable (Glaser \& Strauss, 1967). In particular, among the inductive qualitative analyses to use, a single case study method is chosen for the present paper (Eisenhardt, 1989; Yin, 1994). Starting from a single and very detailed case study, this method allows building ex nihilo one or more theoretical propositions that might be generalised from one brand to a whole industry. Further researches, supporting or denying them, might drive the proposal of a general theory or a model (Dyer \& Wilkins, 1991; Eisenhardt \& Graebner, 2007).

The process of data collection and validation can be divided into several phases. For a start, secondary data were collected from magazines and newspapers and from the brand's website. After this, primary data were collected through semi-structured interviews with open-ended questions. Three in-depth face-to-face interviews were carried out at the level of top management. Answers to the questions were transcribed, read and harmonised. Finally, the answers were discussed again with the top managers previously interviewed in order to validate them. This was done in order to follow standard practices in qualitative studies (Miles \& Huberman, 1984).

\section{The Case Study: The internationalisation Process of leBebè}

In 2007, Lucebianca, an Italian company in the jewellery industry, created leBebè jewels, a brand representing the well-known made in Italy. The idea inspiring this brand was to celebrate the birth of babies, a joy shared by women worldwide. In just a few years, pregnant women have come to consider leBebè jewels a must have product. Net sales have grown constantly and, currently, the brand is among the main players in the jewellery industry (and not only, since it works in several industries by offering different products). In Table 1, the milestones of the growth process are outlined. 
Table 1. The milestones of the leBebè growth process

\begin{tabular}{|c|c|}
\hline Year & Milestone \\
\hline 2007 & The charm leBebè is launched on the market \\
\hline 2009 & $\begin{array}{l}\text { The brand enters the jewellery world by participating in the Vicenza fair, the most important event of the jewellery } \\
\text { industry in Italy }\end{array}$ \\
\hline 2009 & leBebè rings, bracelets and earrings are launched on the market \\
\hline 2011 & The product range is extended by including the leBebè watch \\
\hline 2012 & The product range is extended again by including leBebè frames, lamps and albums \\
\hline 2013 & The product range is extended one more time by including leBebè bonbonnières, candles and other accessories \\
\hline 2014 & The first jewel dedicated to children is introduced to markets with proper packaging and a building box as a shopper \\
\hline 2014 & The first limited edition of leBebè jewels is designed \\
\hline 2015 & A new line of leBebè jewels is designed for pregnant women \\
\hline 2015 & The product range is extended one more time by including leBebè clothes, accessories and shoes \\
\hline
\end{tabular}

Source: www.lebebe.eu.

In reference to its international marketing strategy, leBebè managers have made very interesting choices. The holding company, Lucebianca, decided to open a monobrand office in Rome that is only dedicated to the internationalisation process of leBebè jewels. This underlines that the holding company has invested a lot of time and resources on the internationalisation process of this brand, and these efforts seem to be successful. Currently, leBebè jewels are distributed on four continents: Europe, Africa, Asia, and America. Across them, some of the most interesting countries are Romania, Spain, France, Morocco, South Korea, China and Japan. In these countries, the brand has achieved very positive results in terms of net sales.

At this stage, it is interesting to investigate if leBebè's international marketing strategy is standardised or adapted. In this vein, a direct question was asked of the interviewed top managers who responded: "leBebè brand adopts a standardised international marketing strategy. The monobrand office supervises that -all over the countries - product, pricing, placement and promotion are the same".

According to the above answer, more questions about the 4Ps were asked.

As for the product, "standardisation is obvious", as some top managers declared. All leBebè jewels represent a stylised baby girl or boy (with no somatic feature) so there is no need for adaptation. Moreover, the products are made in Italy and so consumers recognise the high standards (quality and prestige) of leBebè jewels. Despite these premises, an intriguing issue emerged during the interviews. Even if the international marketing strategy is standardised and even if the jewels represent a stylised baby that does not need any adaptation, there is an exception. In Morocco, in fact, consumers have asked for a different quality of jewels realised in 18-carat gold rather than 9-carat gold, because the local culture attributes lower standards (quality and prestige) to the latter. In order to respect the local culture, it was necessary to adapt the jewels, and this seems to have been the right choice since net sales are positive in Morocco.

As for pricing, leBebè jewels are sold according to a differentiation strategy so that prices are a slightly higher than similar products. Because they have no direct competitors, they can ask for a premium price at subsidiaries distributing leBebè jewels. In this case, the monobrand office located in Rome supervises that this policy is applied worldwide. However, when talking with the top manager responsible for distribution, an interesting point was underlined. The top manager declared that "price has been modified in France where subsidiaries ask for higher profit margins and so they want to buy the product at a lower price". France is a country where luxury industries - including jewellery - have a long tradition. Some very famous jewellery brands are produced in France; thus, competition is fierce. In this vein, a lower price at subsidiaries can be a factor that can support and foster distribution of foreign products. This seems to be happening to leBebè jewels, and practicing a lower price appears to have been the right choice. In addition, France is among the most interesting countries where net sales are positive. Then, it is possible to ascertain that leBebè top managers standardise pricing throughout the world, except in France.

As for placement, from the onset of the interviews, the top managers argued that "a standardised international marketing strategy is the aim to pursue. Up to now the brand is new-it was created ten years ago - and so it still suffers a kind of liability of newness". Generally speaking, placement is expected to be managed by subsidiaries who, in turn, distribute the product to stores. In order to make subsidiaries feel involved in the brand, they are informed about the way products are realised. However, from the interviews, it is clear that placement is chosen according to contractual power exerted by Lucebianca. According to this, several differences emerge across countries. In Spain, for example, Lucebianca leverages direct channels to sell leBebè jewels. In Japan, on the 
contrary, the brand leverages indirect channels with several intermediates. Standardisation is far from being completely achieved.

Eventually, the interviewed top managers argued that promotion is managed in an unusual way, leaning towards standardisation. The brand destines a part of the sales realised by subsidiaries to promotion. The monobrand office that tries to fit (according to the budget available in each country) the promotion with the original concept of leBebè assumes all the choices about promotion, from the colours to the channels of communication (newspapers and commercials), passing through to packaging and in-store furnishings (dedicated totems and corners). However, it is not guaranteed that the promotional activities are the same in all countries, since they depend on the sales realised by subsidiaries. Even if promotion is standardised in terms of basic concepts, it can happen that it is not implemented in the same way across all countries.

As explained in the methodological section, the collected answers were discussed again with the top managers previously interviewed in order to validate them. This step was really fruitful since leBebè top managers disclosed their true position about their international marketing strategy. In their view, "the international marketing strategy aspires to be standardised but — whenever and wherever it is necessary — the brand is ready to adapt it in order to respond to the consumers' culture and local expectations".

\section{Results, Discussion and Conclusion}

At the end of the interviews, the top managers declared that "leBebè aspires to a standardised international marketing strategy even if, by now, it is still far from this". The brand, which has been on the market for 10 years, still needs to improve its prominence (Han, Nunes, \& Drèze, 2010) in the jewellery industry and, thus, consumers' cultures and local expectations influence brand decisions.

Based on the interviews, even if the product is standardised (a stylised baby with no somatic feature), some differences exist in reference to its weight in carats. The case of Morocco is rather clear. Customers are not willing to buy leBebè products as they are sold in other countries since they are not of a high standard (quality and prestige) according to their culture. As underlined by the interviewed top managers, Morocco is a promising market and, therefore, it is worth modifying the product in order to satisfy the local requests. As for pricing, the need for adaptation emerged in reference to France. The fact that leBebè does not have strong contractual power with subsidiaries compels the practice of lowering prices, so that subsidiaries feel motivated to support the brand. This means that leBebè jewels suffer the dynamics of the French jewellery industry. In reference to placement, several differences exist across countries (Spain and Japan are two opposite examples) and a lot of work is still necessary to standardise this issue. Eventually, the interviews with the top managers revealed that promotions are thought of in a standardised way, but they are implemented according to the conditions taking place in each country.

The analysis of the international marketing strategy defined and implemented by the leBebè brand offers three very intriguing insights to discuss.

First, standardisation and adaptation are two theoretical constructions that do not represent real choices made by brands. Very often, in fact, brands adapt one or more issues of the marketing mix in reference to one or more countries. This is a common praxis that nullifies the standardisation-adaptation dichotomy and exalts the contingency perspective.

Second, an important aspect that really matters when implementing international marketing strategies is brand prominence. Local brands, generally SMEs, suffer the liability of newness (Freeman, Carroll, \& Hannan, 1983). This gives them low contractual power, which necessarily affects the implementation of international marketing strategies.

Third and last, it is not possible to underestimate the relevance of the industry in which brands operate. Each industry has specific dynamics that necessarily affect the way decisions are made and implemented. Brands cannot ignore these dynamics.

In conclusion, from the results of the above analysis, brand prominence and industry affect the implementation of international marketing strategies in a massive way. Consequently, it is appropriate to wonder if and to what extent brands need to define and plan standardisation or adaptation of their international marketing strategies.

Undoubtedly, this is a theoretical speculation derived from a single case study that — as often underlined (Dyer \& Wilkins, 1991; Eisenhardt \& Graebner, 2007) — still needs to be debated and, of course, further investigations are strongly recommended in order to validate or deny the achieved results. 


\section{Acknowledgments}

Although this article is the result of a joint effort of analysis and reflection, DM authored sections 1, 2, 3 and 5 and GV authored section 4. Both the authors read and approved the final manuscript.

\section{References}

Akgün, A. E., Keskin, H., \& Ayar, H. (2014). Standardization and adaptation of international marketing mix activities: A case study. Procedia-Social and Behavioral Sciences, 150, 609-618. https://doi.org/10.1016/j.sbspro.2014.09.080

Alashban, A. A., Hayes, L. A., Zinkhan, G. M., \& Balazs, A. L. (2002). International brand-name standardization/adaptation: Antecedents and consequences. Journal of International Marketing, 10(3), 22-48. https://doi.org/10.1509/jimk.10.3.22.19544

Atwal, G., \& Williams, A. (2009). Luxury brand marketing - the experience is everything!. Journal of Brand Management, 16(5-6), 338-346. https://doi.org/10.1057/bm.2008.48

Bain \& Company. (2015). Luxury Goods Worldwide Market Study. Fall-Winter 2015 A Time to Act-How Luxury Brands Can Rebuild to Win. Retrieved from http://www.bain.com/publications/articles/luxury-goods-worldwide-market-study-winter-2015.aspx

Baker, J., Ashill, N., Amer, N., \& Diab, E. (2018). The Internet dilemma: An exploratory study of luxury firms' usage of internet-based technologies. Journal of Retailing and Consumer Services, 41, 37-47. https://doi.org/10.1016/j.jretconser.2017.11.007

Birnik, A., \& Bowman, C. (2007). Marketing mix standardization in multinational corporations: a review of the evidence. International Journal of Management Reviews, 9(4), 303-324. https://doi.org/10.1111/j.1468-2370.2007.00213.x

Boddewyn, J. J., \& Grosse, R. (1995). American marketing in the European Union: standardization's uneven progress (1973-1993). European Journal of Marketing, 29(12), 23-42. https://doi.org/10.1108/03090569510102513

Boso, N., Story, V. M., Cadogan, J. W., Micevski, M., \& Kadić-Maglajlić, S. (2013). Firm innovativeness and export performance: environmental, networking, and structural contingencies. Journal of International Marketing, 21(4), 62-87. https://doi.org/10.1509/jim.13.0052

Calantone, R. J., Kim, D., Schmidt, J. B., \& Cavusgil, S. T. (2006). The influence of internal and external firm factors on international product adaptation strategy and export performance: a three-country comparison. Journal of Business Research, 59(2), 176-185. https://doi.org/10.1016/j.jbusres.2005.05.001

Cavusgil, S. T., \& Zou, S. (1994). Marketing strategy-performance relationship: an investigation of the empirical link in export market ventures. The Journal of Marketing, 58(1), 1-21. https://doi.org/10.2307/1252247

Cavusgil, S. T., Zou, S., \& Naidu, G. M. (1993). Product and promotion adaptation in export ventures: an empirical investigation. Journal of International Business Studies, 24(3), 479-506. https://doi.org/10.1057/palgrave.jibs.8490242

Chandra, A., Griffith, D. A., \& Ryans Jr, J. K. (2002). Advertising standardization in India: US multinational experience. International Journal of Advertising, 21(1), 47-66. https://doi.org/10.1080/02650487.2002.11104916

Chung, H. F. L., Wang, C. L., \& Huang, P. H. (2012). A contingency approach to international marketing strategy and decision-marketing structure among exporting firms. International Marketing Review, 29(1), 54-87. https://doi.org/10.1108/02651331211201543

De Luz, M. (1993). Relationship between export strategy variables and export performance for Brazil-based manufacturers. Journal of Global Marketing, 7(1), 87-110. https://doi.org/10.1300/J042v07n01_06

Douglas, S. P., \& Wind, Y. (1987). The myth of globalization. Columbia Journal of World Business, 22(4), 19-29.

Dunning, J. H. (1993). Internationalizing Porter's diamond. MIR: Management International Review, 33(2 special issue), 7-15.

Dyer, W. G., \& Wilkins, A. L. (1991). Better stories, not better constructs, to generate better theory: a rejoinder to Eisenhardt. The Academy of Management Review, 16(3), 613-619. https://doi.org/10.5465/AMR.1991.4279492 
Eisenhardt, K. M. (1989). Building theories from case study research. The Academy of Management Review, 14(4), 532-550. https://doi.org/10.5465/AMR.1989.4308385

Eisenhardt, K. M., \& Graebner, M. E. (2007). Theory building from cases: opportunities and challenges. The Academy of Management Journal, 50(1), 25-32. https://doi.org/10.5465/AMJ.2007.24160888

Freeman, J., Carroll, G. R., \& Hannan, M. T. (1983). The liability of newness: Age dependence in organizational death rates. American Sociological Review, 48(5), 692-710. https://doi.org/10.2307/2094928

Glaser, B. G., \& Strauss, A. L. (1967). The Discovery of Grounded Theory: Strategies for Qualitative Research. London, UK: Weidenfeld and Nicholson.

Goi, C. L. (2009). A review of marketing mix: 4Ps or more?. International Journal of Marketing Studies, 1(1), 2-16. http://dx.doi.org/10.5539/ijms.v1n1p2

Griffith, D. A., Chandra, A., \& Ryans Jr, J. K. (2003). Examining the intricacies of promotion standardization: factors influencing advertising message and packaging. Journal of International Marketing, 11(3), 30-47. https://doi.org/10.1509/jimk.11.3.30.20160

Griffith, D. A., Lee, H. S., Yeo, S. C., \& Calantone, R. (2014). Marketing process adaptation: Antecedent factors and new product performance implications in export markets. International Marketing Review, 31(3), 308-334. https://doi.org/10.1108/IMR-06-2013-0113

Griffith, D. A., \& Myers, M. B. (2005). The performance implications of strategic fit of relational norm govern strategies in global supply chain relationships. Journal of International Business Studies, 36(3), 254-269. https://doi.org/10.1057/palgrave.jibs.8400131

Han, Y. J., Nunes, J. C., \& Drèze, X. (2010). Signaling status with luxury goods: The role of brand prominence. Journal of Marketing, 74(4), 15-30. https://doi.org/10.1509/jmkg.74.4.15

Johnson, J. L., \& Arunthanes, W. (1995). Ideal and actual product adaptation in US exporting firms: market-related determinants and impact on performance. International Marketing Review, 12(3), 31-46. https://doi.org/10.1108/02651339510091726

Katsikeas, C. S., Samiee, S., \& Theodosiou, M. (2006). Strategy fit and performance consequences of international marketing standardization. Strategic Management Journal, 27(9), 867-890. https://doi.org/10.1002/smj.549

Keller, K. L. (2010). Brand equity management in a multichannel, multimedia retail environment. Journal of Interactive Marketing, 24(2), 58-70. https://doi.org/10.1016/j.intmar.2010.03.001

Kotler, P. (1986). Global standardization-courting danger. Journal of Consumer Marketing, 3(2), 13-15. https://doi.org/10.1108/eb008158

Kustin, R. A. (2004). Marketing mix standardization: a cross-cultural study of four countries. International Business Review, 13(5), 637-649. https://doi.org/10.1016/j.ibusrev.2004.07.001

Leonidou, L. C. (1996). Product standardization or adaptation: the Japanese approach. Journal of Marketing Practice: Applied Marketing Science, 2(4), 53-71. https://doi.org/10.1108/EUM0000000004136

Lee, B., Collier, P. M., Cullen, J. (2007). Reflections on the use of case studies in the accounting, management and organizational disciplines. Qualitative Research in Organizations and Management: An International Journal, 2(3), 169-178. https://doi.org/10.1108/17465640710835337

Levitt, T. (1983). The globalization of markets. Harvard Business Review, 61, 92-102.

Loyka, J. J., \& Powers, T. L. (2003). A model of factors that influence global product standardization. Journal of Leadership \& Organizational Studies, 10(N), 64-72. https://doi.org/10.1177/107179190301000207

McKinsey \& Company. (2014). A Multifaceted Future: The Jewelry Industry in 2020. Retrieved from www.mckinsey.com/industries/retail/our-insights/a-multifaceted-future-the-jewelry-industry-in-2020

Miles, M. B., \& Huberman, A. M. (1984). Qualitative Data Analysis. Beverly Hills, CA: Sage Publications.

Morgan, N. A., Kaleka, A., \& Katsikeas, C. S. (2004). Antecedents of export venture performance: A theoretical model and empirical assessment. Journal of Marketing, 68(1), 90-108. https://doi.org/10.1509/jmkg.68.1.90.24028

Ohmae, K. (1989). Managing in a borderless world. Harvard Business Review, 67(3), 152-161.

Okonkwo, U. (2009). Sustaining the luxury brand on the Internet. Journal of Brand Management, 16(5-6), 
302-310. https://doi.org/10.1057/bm.2009.2

Omar, O. (2008). International Marketing. Gordonsville, US: Palgrave Macmillan Publication.

Onkvisit, S., \& Shaw, J. J. (1999). Standardized international advertising: some research issues and implications. Journal of Advertising Research, 39(6), 19-24.

Porter, M. (1986). The strategic role of international marketing. Journal of Consumer Marketing, 3(2), 17-21. https://doi.org/10.1108/eb008159

Powers, T. L., \& Loyka, J. J. (2007). Market, industry, and company influences on global product standardization. International Marketing Review, 24(6), 678-694. https://doi.org/10.1108/02651330710832658

Powers, T. L., \& Loyka, J. J. (2010). Adaptation of marketing mix elements in international markets. Journal of Global Marketing, 23(1), 65-79. https://doi.org/10.1080/08911760903442176

Ryans Jr, J. K., Griffith, D. A., \& White, S. D. (2003). Standardization/adaptation of international marketing strategy: Necessary conditions for the advancement of knowledge. International Marketing Review, 20(6), 588-603. https://doi.org/10.1108/02651330310505204

Samli, A. C., \& Jacobs, L. W. (1995). Pricing practices of American multinational firms: standardization vs. localization dichotomy. Journal of Global Marketing, 8(2), 51-74. https://doi.org/10.1300/J042v08n02_04

Sanguanpiyapan, T., \& Jasper, C. (2010). Consumer insights into luxury goods: Why they shop where they do in a jewelry shopping setting. Journal of Retailing and Consumer Services, 17(2), 152-160. https://doi.org/10.1016/j.jretconser.2009.12.001

Schmid, S., \& Kotulla, T. (2011). 50 years of research on international standardization and adaptation-From a systematic literature analysis to a theoretical framework. International Business Review, 20(5), 491-507. https://doi.org/10.1016/j.ibusrev.2010.09.003

Shoham, A. (1996). Marketing-mix standardization: determinants of export performance. Journal of Global Marketing, 10(2), 53-73. https://doi.org/10.1300/J042v10n02_04

Shoham, A. (2003). Standardization of international strategy and export performance: a meta-analysis. Journal of Global Marketing, 16(1-2), 97-120. https://doi.org/10.1300/J042v16n01_05

Silverstein, M. J., \& Fiske, N. (2003). Luxury for the masses. Harvard Business Review, 81(4), 48-57.

Sirisagul, K. (2000). Global advertising practices: a comparative study. Journal of Global Marketing, 14(3), 77-97. https://doi.org/10.1300/J042v14n03_05

Solberg, C. A. (2000). Standardization or adaptation of the international marketing mix: the role of the local subsidiary/representative. Journal of International Marketing, 8(1), 78-98. https://doi.org/10.1509/jimk.8.1.78.19559

Sorenson, R. Z., \& Wiechmann, U. E. (1975). How multinationals view marketing standardization. Harvard Business Review, 53(38-56), 166-167.

Strauss, A., \& Cobin, J. (1990). Basics of Qualitative Research. Newbury Park, CA: Sage Publications.

Tan, Q., \& Sousa, C. M. (2011). Research on export pricing: Still moving toward maturity. Journal of International Marketing, 19(3), 1-35. https://doi.org/10.1509/jimk.19.3.1

Theodosiou, M., \& Katsikeas, C. S. (2001). Factors influencing the degree of international pricing strategy standardization of multinational corporations. Journal of International Marketing, 9(3), 1-18. https://doi.org/10.1509/jimk.9.3.1.19928

Theodosiou, M., \& Leonidou, L. C. (2003). Standardization versus adaptation of international marketing strategy: an integrative assessment of the empirical research. International Business Review, 12(2), 141-171. https://doi.org/10.1016/S0969-5931(02)00094-X

Tynan, C., McKechnie, S., \& Chhuon, C. (2010). Co-creating value for luxury brands. Journal of Business Research, 63(11), 1156-1163. https://doi.org/10.1016/j.jbusres.2009.10.012

Vernon, R. (1966). International investment and international trade in the product cycle. The Quarterly Journal of Economics, 80(2), 190-207. https://doi.org/10.2307/1880689

Vickers, J. S., \& Renand, F. (2003). The marketing of luxury goods: An exploratory study-three conceptual dimensions. The Marketing Review, 3(4), 459-478. https://doi.org/10.1362/146934703771910071

Viswanathan, N. K., \& Dickson, P. R. (2007). The fundamentals of standardizing global marketing strategy. 
International Marketing Review, 24(1), 46-63. https://doi.org/10.1108/02651330710727187

Vrontis, D., \& Papasolomou, I. (2005). The use of entry methods in identifying multinational companies' AdaptStand behavior in foreign markets. Review of Business, 26(1), 13-20.

Vrontis, D., Thrassou, A., \& Lamprianou, I. (2009). International marketing adaptation versus standardisation of multinational companies. International Marketing Review, 26(4/5), 477-500. https://doi.org/10.1108/02651330910971995

Yeoman, I., \& McMahon-Beattie, U. (2006). Luxury markets and premium pricing. Journal of Revenue and Pricing Management, 4(4), 319-328. https://doi.org/10.1057/palgrave.rpm.5170155

Yin, R. K. (1993). A Review of Case Study: Research, Design and Methods. Newbury Park, CA: Sage Publications.

Yin, R. K. (1994). Discovering the future of the case study method in evaluation research. Evaluation Practice, 15(3), 283-290. https://doi.org/10.1016/0886-1633(94)90023-X

Zou, S., \& Cavusgil, S. T. (2002). The GMS: A broad conceptualization of global marketing strategy and its effect on firm performance. Journal of Marketing, 66(4), 40-56. https://doi.org/10.1509/jmkg.66.4.40.18519

\section{Copyrights}

Copyright for this article is retained by the author, with first publication rights granted to the journal.

This is an open-access article distributed under the terms and conditions of the Creative Commons Attribution license (http://creativecommons.org/licenses/by/4.0/). 